University of Nebraska - Lincoln

DigitalCommons@University of Nebraska - Lincoln

Biological Systems Engineering: Papers and

Publications

Biological Systems Engineering

2012

\title{
Carbon, water, and heat flux responses to experimental burning and drought in a tallgrass prairie
}

\author{
Marc L. Fischer \\ Lawrence Berkeley National Laboratory, mlfischer@lbl.gov \\ M S. Torn \\ Lawrence Berkeley National Laboratory, mstorn@lbl.gov \\ David P. Billesbach \\ University of Nebraska-Lincoln, dbillesbach1@unl.edu \\ Geoffrey Doyle \\ Aberdeen Proving Grounds, geoffrey.I.doyle@saic.com \\ Brian Northup \\ USDA Grazing Lands Research Laboratory, brian.northup@ars.usda.gov \\ See next page for additional authors
}

Follow this and additional works at: https://digitalcommons.unl.edu/biosysengfacpub

Part of the Biological Engineering Commons

Fischer, Marc L.; Torn, M S.; Billesbach, David P.; Doyle, Geoffrey; Northup, Brian; and Biraud, Sebastien C., "Carbon, water, and heat flux responses to experimental burning and drought in a tallgrass prairie" (2012). Biological Systems Engineering: Papers and Publications. 231.

https://digitalcommons.unl.edu/biosysengfacpub/231

This Article is brought to you for free and open access by the Biological Systems Engineering at DigitalCommons@University of Nebraska - Lincoln. It has been accepted for inclusion in Biological Systems Engineering: Papers and Publications by an authorized administrator of DigitalCommons@University of Nebraska Lincoln. 


\section{Authors}

Marc L. Fischer, M S. Torn, David P. Billesbach, Geoffrey Doyle, Brian Northup, and Sebastien C. Biraud 


\title{
Carbon, water, and heat flux responses to experimental burning and drought in a tallgrass prairie
}

\author{
Marc L. Fischer ${ }^{\mathrm{a}, *}$, Margaret S. Torn ${ }^{\mathrm{a}}$, David P. Billesbach ${ }^{\mathrm{b}}$, Geoffrey Doyle $^{\mathrm{c}}$, Brian Northup $^{\mathrm{d}}$, \\ Sebastien C. Biraud ${ }^{\mathrm{a}}$ \\ a Lawrence Berkeley National Laboratory, 1 Cyclotron Road, Berkeley, CA 94720, United States \\ ${ }^{\mathrm{b}}$ Department of Biological Systems Engineering, University of Nebraska, Lincoln, NE 68583, United States \\ c Science Applications International Corp., Aberdeen Proving Grounds, MD 21010, United States \\ d USDA Grazing Lands Research Laboratory, El Reno, OK 73036, United States
}

\section{A R T I C L E I N F O}

\section{Article history:}

Received 7 July 2011

Received in revised form 14 July 2012

Accepted 17 July 2012

\section{Keywords:}

Grassland

Prairie

Fire

Eddy covariance

Carbon exchange

Water stress

\begin{abstract}
A B S T R A C T
Drought and fire are common disturbances to grassland ecosystems. We report two years of eddy covariance ecosystem-atmosphere fluxes and biometric variables measured in nearby burned and unburned pastures in the US Southern Great Plains. Over the course of the experiment, annual precipitation $\left(\sim 600 \mathrm{~mm} \mathrm{yr}^{-1}\right)$ was lower than the long term mean $\left(\sim 860 \mathrm{~mm} \mathrm{yr}^{-1}\right)$. Soil moisture decreased from productive conditions in March 2005 dry, unproductive conditions during the growing season starting in March 2006. Just prior to the burn in early March 2005, burned and unburned pastures contained $520 \pm 60$ and $360 \pm 40 \mathrm{~g} \mathrm{C} \mathrm{m}^{-2}$ of total above ground biomass (AGB) and litter, respectively. The fire removed approximately $200 \mathrm{~g} \mathrm{C} \mathrm{m}^{-2}$ of litter and biomass. In the 2005 growing season following the burn, maximum green AGB was $450 \pm 60$ and $270 \pm 40 \mathrm{~g} \mathrm{C} \mathrm{m}^{-2}$, with corresponding cumulative annual net ecosystem carbon exchange (NEE) of -330 and $-150 \mathrm{~g} \mathrm{C} \mathrm{m}^{-2}$ for the burned and unburned pastures, respectively. In contrast to NEE, cumulative mean sensible heat and water fluxes were approximately equal in both pastures during the growing season, suggesting either an increase in water use efficiency or a decrease in evaporation in the burned relative to the unburned pasture. In the 2006 growing season, dry conditions decreased carbon uptake and latent heat, and increased sensible heat fluxes. Peak AGB was reduced to $210 \pm 30 \mathrm{~g} \mathrm{C} \mathrm{m}^{-2}$ and $140 \pm 30 \mathrm{~g} \mathrm{C} \mathrm{m}^{-2}$ in the burned and unburned pastures, respectively, while NEE was near zero. These results suggest that the lack of precipitation was responsible for most of the interannual variation in carbon exchange for these un-irrigated prairie pastures.
\end{abstract}

(c) 2012 Elsevier B.V. All rights reserved.

\section{Introduction}

Grasslands cover more than $20 \%$ of the Earth's land surface and contain about $10 \%$ of terrestrial carbon (Schimel, 1995; Schlesinger, 1997). While native tallgrass and shortgrass prairies once dominated the Great Plains of North America, most of that land has been converted to row-crop agriculture. Of the remaining Great Plains grasslands, some are non-native and include significant cover of introduced species, but many pastures within the US Federal Crop Reserve Program are relatively undisturbed by introduced species.

\footnotetext{
* Corresponding author at: MS 90K-125, Lawrence Berkeley National Laboratory, 1 Cyclotron Road, Berkeley, CA 94720, United States. Tel.: +1 510486 5539; fax: +1 5104865928 .

E-mail addresses: mlfischer@lbl.gov (M.L. Fischer), mstorn@lbl.gov (M.S. Torn), dbillesbach1@unl.edu (D.P. Billesbach), geoffrey.l.doyle@saic.com (G. Doyle), brian.northup@ars.usda.gov (B. Northup), scbiraud@lbl.gov (S.C. Biraud).
}

Grasslands play a time varying role in the carbon cycle for North America (Frank and Dugas (2001), Meyers (2001) and Sims and Bradford (2001), King et al., 2007). Net ecosystem carbon exchange, $\mathrm{NEE}=\left(R_{\mathrm{eco}}-\mathrm{GPP}\right)$, where $R_{\text {eco }}$ and GPP are gross respiratory and production fluxes, has been measured in grasslands to range from +155 to $-274 \mathrm{~g} \mathrm{C} \mathrm{m}^{-2} \mathrm{yr}^{-1}$ (where negative flux represents carbon uptake by the ecosystem). NEE is hence sensitive to the balance of between growth and decomposition, where $R_{\text {eco }}$ can range from 900 to over $2000 \mathrm{~g} \mathrm{C} \mathrm{m}^{-2} \mathrm{yr}^{-1}$ (Norman et al., 1992; Knapp et al., 1988; Bremer and Ham, 2010; Mielnick and Dugas, 2000; Suyker et al., 2003; Harper et al., 2005; Zhou et al., 2006; Bremer and Ham, 2010; Zhang et al., 2011).

Two factors driving inter-annual variability in carbon exchange are water limitation (e.g., Flanagan and Johnson, 2005; Harper et al., 2005; Polley et al., 2008; Svejcar, 2008), and land management (Owensby et al., 2006; Polley et al., 2008). Previous studies have found that burning at intervals affect carbon cycling by increasing above ground biomass production (Gale et al., 1990; Heisler et al., 2003), soil respiration (Knapp et al., 1988), and soil carbon 
storage (Dai et al., 2006), though carbon responses are likely to be dependent on available moisture (Bremer and Ham, 2010). In terms of atmospheric carbon inputs, the largest and most immediate effect of fire will be the short pulse of combustion products $\left(\mathrm{CO}_{2}, \mathrm{CO}\right.$, soot, etc.) released during the actual burn. For the purposes of this work, we define net biome production, NBP, so that it includes carbon lost due to fire, $C_{\text {fire }}$ as NBP $=\mathrm{GPP}-R_{\mathrm{eco}}-C_{\text {fire }}$ (Randerson et al., 2002).

To improve our understanding of the effects of drought and fire on a grassland ecosystem, we evaluate measurements of carbon, water, and heat exchanges in burned and unburned pastures of native prairie over a two-year period when precipitation was below the historical mean.

\section{Methods}

\subsection{Site description and burning treatment}

The measurements were conducted in two adjacent 33 ha pastures at the United States Department of Agriculture - Agricultural Research Service (USDA-ARS) Grazing Lands Research Laboratory (GRL) located near El Reno, Oklahoma $\left(35^{\circ} 33^{\prime} \mathrm{N}, 98^{\circ} 02^{\prime} \mathrm{W}, 423 \mathrm{~m}\right.$ asl). The soil is classified as Norge loamy prairie (Fine, mixed, thermic Udertic Paleustalf) with a depth greater than $1 \mathrm{~m}$, high water holding capacity, and slope averaging about 1\% (USDA-NRCS, 1999). Dominant species included big bluestem (Andropogon gerardi Vitman), little bluestem (Schizachyrium halapense (Michx.) Nash.), and others common to tallgrass prairie ecosystems. Both pastures also had infestations of non-native annual bromes (Bromus japonicus Thunb; Bromus tectorum L.) present within plant communities. Both pastures had not been burned since 1990, but were occasionally sprayed with a broad-leaf herbicide, and grazed at equal and moderate stocking rates through the year 2000 growing season. On March 9 (DOY 68), 2005 the northern (treatment) pasture was burned by starting a fire line on the upwind side of the pasture after clearing a litter from the downwind edge. Because the litter layer was still somewhat moist (though unmeasured) in early March and winds were not strong $\left(<5 \mathrm{~m} \mathrm{~s}^{-1}\right)$, the fire was not hot enough to consume all of the litter.

\subsection{Ecological measurements}

Above ground biomass (AGB) was sampled several weeks prior to and immediately following the burn, and monthly during the growing seasons for the remainder of the experiment. On each sampling date, ten $0.25 \mathrm{~m}^{2}$ sampling squares were collected at approximately $40 \mathrm{~m}$ spacing along north-south transects, passing near the flux towers. The collected materials were divided into green vegetation, standing dead material, and litter. Green vegetation and standing dead were also separated into functional groups (cool season (C3) annual and perennial grasses, warm season (C4) annual and perennial grasses, and forbs). In each case, the above ground biomass (AGB) was estimated by weighing dried (24-72 hr at $60^{\circ} \mathrm{C}$ ) samples. The carbon content of the green vegetation and dead biomass was measured using Carlo Erba $C \& N$ analyzer to be approximately 0.45 and 0.40 , respectively.

\subsection{Micro-meteorological measurements}

Surface flux measurements were made with two portable eddy covariance systems described previously (Billesbach et al., 2004). Briefly, the eddy covariance instruments included a sonic anemometer (Gill-Solent WindMaster Pro, Gill-Solent, Lymington, UK), and an open-path infrared gas analyzer (IRGA LiCor LI-7500, LiCor Biosciences, Lincoln, NE). The anemometer and IRGA were located $4 \mathrm{~m}$ above the ground, allowing a minimum of $\sim 3 \mathrm{~m}$ between the top of the canopy. Calibrations of the IRGAs were performed annually; immediately prior to the experiment, in March 2006, and at the completion of the experiment. In all cases, changes in the IRGA gains were less than $1 \%$. RS232 data streams from the sonic anemometer and the IRGA were synchronized and recorded on small single board computers (Arcom Inc.) running dedicated software (Billesbach, private communication).

The slow response data systems associated with the flux towers (Billesbach et al., 2004) consisted of a set of six type E soil temperature thermocouples and a set of four ML-2 (Delta-T Devices Ltd., Cambridge, England) theta probe moisture sensors. The soil temperature probes were installed at depths of 5,15 , and $25 \mathrm{~cm}$ with two replicates at each depth. The soil moisture probes were installed at 10 and $30 \mathrm{~cm}$, also with two replicates at each depth. In addition to these instruments, there were four HFT3 (Radiation and Energy Balance Systems, Bellevue, WA) soil heat plates installed about 4-5 cm below the surface, a model NR-lite (Kipp \&Zonen B.V., Delft, The Netherlands) net radiometer, a LI-190 (LiCor Biosciences, Lincoln, NE) PAR sensor, a LiCor LI-200 shortwave pyranometer, a pair of 50-Y Humitter (Vaisala Oyj., Helsinki, Finland) temperature/relative humidity (T/RH) sensors (housed in REBS 6-plate, non-aspirated radiation shields), a Vaisala PT-101B barometer, and a model $525 \mathrm{~mm}$ (Texas Electronics, Dallas, TX) tipping bucket rain gauge. The $\mathrm{T} / \mathrm{RH}$ sensors were mounted on a 4-m tripod tower (Campbell Scientific, Inc., Logan, UT) at $2.5 \mathrm{~m}$ and $3.8 \mathrm{~m}$ above the surface. The radiation sensors were mounted on a long outrigger bar, approximately $2.5 \mathrm{~m}$ above the surface, and the rain gauge was mounted to a fence post located just south of the tripod. All data were recorded on either a Campbell CR23X (Campbell Scientific, Logan, UT) or a CR10X data logger, with extra analog input channels and thermocouple reference temperature provided by a Campbell AM25 T solid-state multiplexor. 30-minute averages were stored and read over an RS232 serial connection by the main eddy covariance computer. These data (as well as the raw eddy covariance data) were downloaded during the biweekly maintenance visits.

\subsection{Eddy flux data processing}

Turbulent vertical fluxes of $\mathrm{CO}_{2}$, water, and heat were calculated every 30 minutes using algorithms for spike removal, coordinate rotation to zero mean vertical and cross wind speed, and block averaging of scalar quantities (Billesbach et al., 2004). Density corrections were applied to the covariances of vertical wind, using $\mathrm{CO}_{2}$ and $\mathrm{H}_{2} \mathrm{O}$ densities obtained with the open-path IRGA (Webb et al., 1980). Small multiplicative (Moore, 1984) spectral corrections (10-15\%) were estimated for a subset of the data, but not applied to the entire data set reported here. Changes in storage of $\mathrm{CO}_{2}$ below the eddy covariance sensors was estimated from changes in $\mathrm{CO}_{2}$ concentration and found to generally be negligible compared with turbulent fluxes, as expected for short statured grass canopies and windy conditions (Suyker et al., 2003; Fischer et al., 2007). Random uncertainties in measured fluxes obtained from averaging turbulence measurements, were estimated to be approximately10\% (Billesbach, 2011). Missing segments of flux data were gap-filled using the method of Falge et al. (2001). Briefly, individual missing points in small gaps (1-4 consecutive points) were filled with linearly interpolated values between neighboring good points. Larger gaps were filled with a mean diurnal cycle determined from a two-week window surrounding the missing data. Nighttime data were replaced when the $1 / 2$ hour averaged friction velocity, $u^{*}=\left\langle-u^{\prime} w^{\prime}\right\rangle^{1 / 2}$, was insufficient to insure adequate turbulence, and $u^{\prime}$ and $w^{\prime}$ are fluctuating components of horizontal and vertical wind. The minimum $u_{*}$ was estimated as the value $\left(u_{*}>0.15 \mathrm{~m} \mathrm{~s}^{-1}\right)$ necessary for nighttime NEE to reach a plateau (Falge et al., 2001). Uncertainty in cumulative exchange was estimated from the range of cumulative NEE obtained by applying 
$u *$ cuts to NEE ranging from 0.1 to $0.2 \mathrm{~m} \mathrm{~s}^{-1} \cdot \mathrm{CO}_{2}$ fluxes were also partitioned into ecosystem respiration using nighttime data fit to an exponential temperature response, and gross uptake using daytime data fit to the combination of a rectangular parabolic light response and ecosystem respiration driven by temperature (from the fit to nighttime data) as described in Fischer et al. (2007).

\subsection{Soil chamber soil respiration measurements}

After the fire, three automated soil $\mathrm{CO}_{2}$ respiration systems (LiCor LI-8100, LiCor Biosciences, Lincoln, NE) were installed in the burned pasture and three were installed in the unburned pasture. Data collection began on April 28, 2005 and continued until March 5, 2007, with a gap for instrument re-calibration between December 14, 2005 and February 9, 2006. Measurements were made at 15 minute intervals. The automated soil respiration systems were installed in accordance with the manufacturer's recommendations with $20 \mathrm{~cm}$ diameter PVC collars inserted into the soil to a depth of approximately $8-10 \mathrm{~cm}$. Power for each unit was provided by $80 \mathrm{~W}$ solar panels connected to a pair of deep cycle $\mathrm{RV} /$ Marine batteries wired in parallel. The solar panel, batteries, and IRGA box for each system were located 1-2 $m$ to the north of each collar. Vegetation was clipped inside the collars biweekly throughout the growing season to prevent interference with the lid closure mechanism. To minimize disturbance of the long-term carbon balance inside the collar, the clippings were scattered inside the collar. Data were processed to estimate $1 / 2$ hourly fluxes and summed to growing season and annual totals, with uncertainties estimated as the root-sum-square of the measurement errors.

\section{Results and discussion}

\subsection{Annual variations in average climate}

The seasonal to inter-annual variations in temperature, humidity, precipitation, and soil moisture are shown in Fig. 1. Cumulative

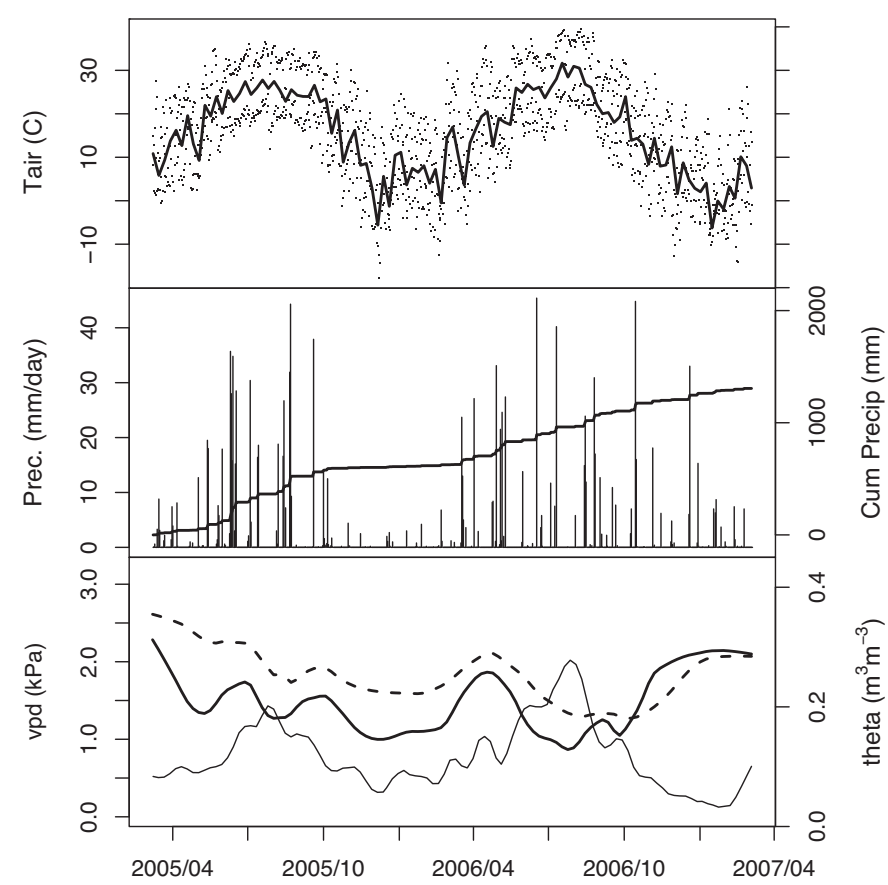

Fig. 1. Daily min, max, and mean (line) air temperature (top), daily (middle, left axis) and cumulative precipitation (middle, right axis), vapor pressure (thin line, left axis) and soil moisture (at $10 \mathrm{~cm}$ thick dashed, and $30 \mathrm{~cm}$ thick solid lines, right axis) measured in the unburned pasture.

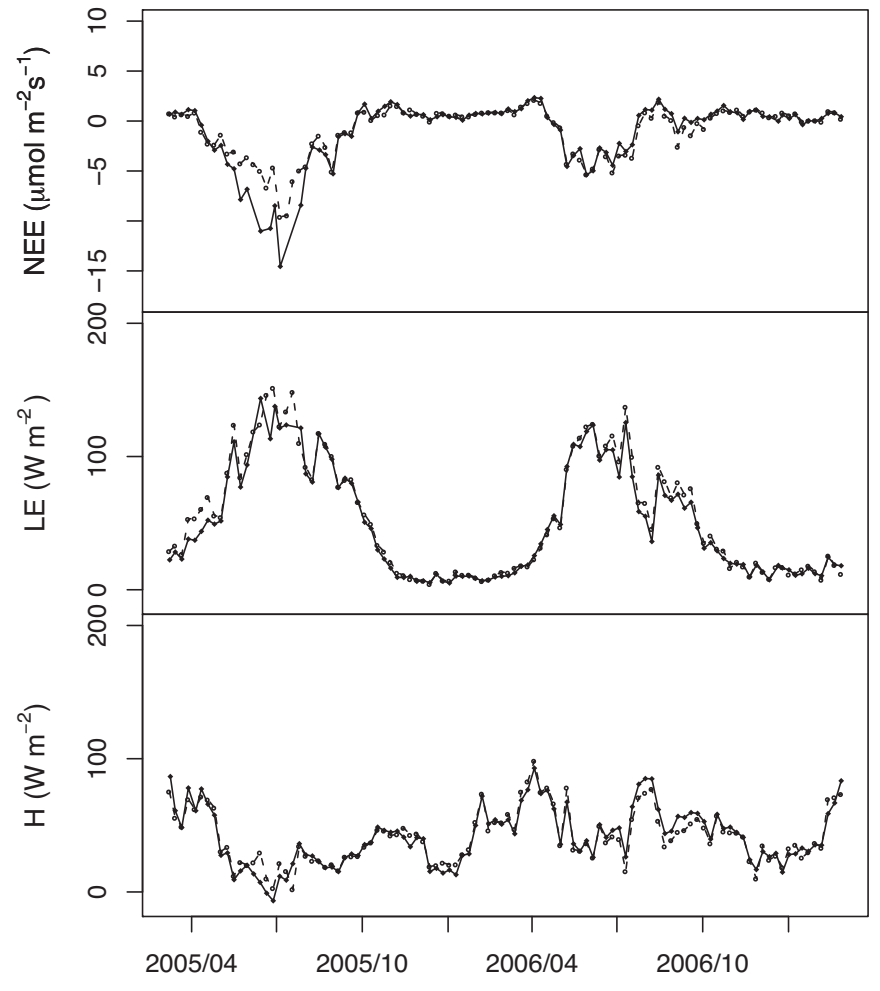

Fig. 2. Weekly mean net ecosystem carbon exchange (NEE, top), latent heat (LE, middle), and sensible heat (bottom) measured in burned (solid circle) and the unburned (open circle) pastures.

annual precipitation were $600 \pm 20 \mathrm{~mm}$ and $620 \pm 30$ in 2005 and 2006, respectively, significantly below the annual average of $860 \mathrm{~mm}$ for the 1971-2000 period (Oklahoma Mesonet). Presumably in response to the limited precipitation, soil moisture gradually declined during the study, increasing the vapor pressure deficit during the 2006 growing season relative to that in 2005 .

\subsection{Annual variations in energy and water fluxes}

Annual cumulative evapotranspiration for burned and unburned pastures totaled $780 \pm 80$ and $850 \pm 90 \mathrm{~mm}$ in 2005 respectively, somewhat greater than the precipitation in 2005 , resulting in gradual soil drying. The sub-normal precipitation continued into 2006, particularly from January to March 2006, which led to even drier soils, lower evapotranspiration (Fig. 2), and greater atmospheric vapor pressure deficits. Cumulative annual evapotranspiration for 2006 totaled $680 \pm 70$ and $730 \pm 70 \mathrm{~mm}$ for the burned and unburned pastures respectively, somewhat less than in 2005, and again slightly exceeding annual precipitation (Table 1).

\subsection{Variations in biomass}

Before the experiment started, total AGB (biomass and litter) in the burned and unburned pastures were $520 \pm 60 \mathrm{~g} \mathrm{C} \mathrm{m}^{-2}$ and $360 \pm 40 \mathrm{~g} \mathrm{C} \mathrm{m}^{-2}$, respectively. The fire removed $200 \pm 70 \mathrm{~g} \mathrm{C} \mathrm{m}^{-2}$ of standing dead biomass and litter. Following the fire, the remaining litter in the burned pasture was rapidly lost to some combination of decomposition and wind erosion, leading to relatively little litter being present at the time of peak green AGB in summer 2005, an effect which was not observed in the unburned pasture (Fig. 3).

Peak biomass in 2005 was $450 \pm 60 \mathrm{~g} \mathrm{C} \mathrm{m}^{-2}$ versus $270 \pm 40 \mathrm{~g} \mathrm{C} \mathrm{m}^{-2}$ in the burned and unburned pastures, respectively. The difference between these values was roughly equivalent 

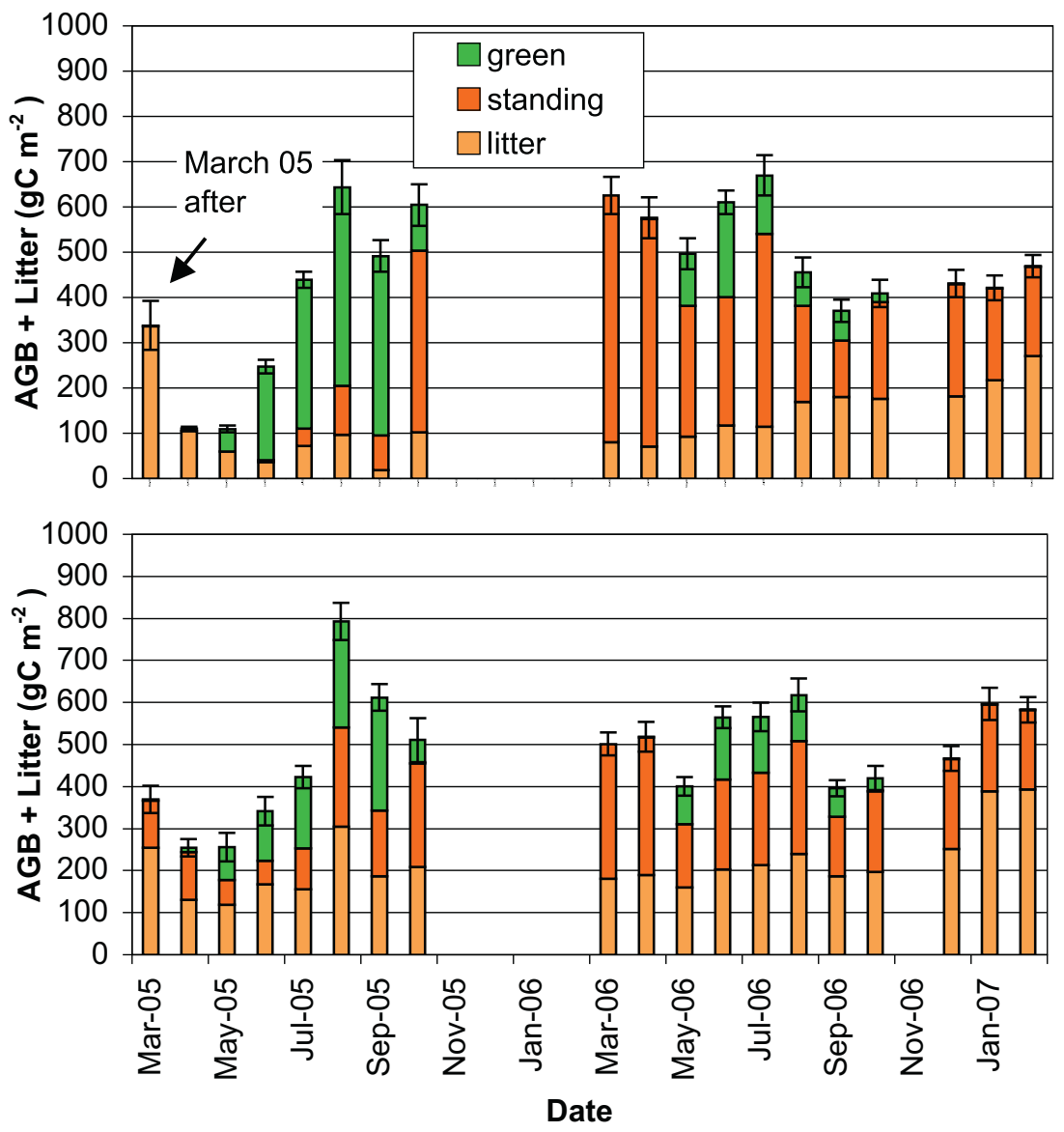

Fig. 3. Above ground biomass measured in burned (bottom) and unburned (top) pastures.

to the amount of carbon lost to the fire, leaving the burned and unburned pastures with similar amounts of above ground carbon in the first year following the fire. In 2006, the maximum green biomass was reduced to $210 \pm 30 \mathrm{~g} \mathrm{C} \mathrm{m}^{-2}$ and $140 \pm 30 \mathrm{~g} \mathrm{C} \mathrm{m}^{-2}$ in the burned and unburned pastures, respectively, a roughly 2 -fold reduction from that in 2005.

\subsection{Variations in carbon dioxide exchange}

Cumulative NEE from March 2005 to March 2006 totaled $-330 \pm 30$ and $-150 \pm 20 \mathrm{~g} \mathrm{Cm}^{-2}$ in the burned and unburned pastures respectively (Table 1 ). However, after including the loss of carbon during the burn, NBP for the two pastures was approximately equal. Cumulative ecosystem respiration was similar for the burned and unburned pastures and totaled about $1850 \pm 200 \mathrm{~g} \mathrm{C} \mathrm{m}^{-2}$ each, where we estimate the error in measured respiration as about $10 \%$ of the cumulative value. This is consistent with measurements of soil respiration made by the automated soil chambers, which were $1860 \pm 40$ and $1830 \pm 40 \mathrm{~g} \mathrm{C} \mathrm{m}^{-2}$ for the burned and unburned pastures respectively.

As shown in Fig. 4, Net carbon exchange was suppressed in 2006 relative to 2005, particularly during the mid-summer period with vapor pressure deficit. For example, daytime uptake was often suppressed in the afternoon relative to morning periods, despite receiving similar amounts of photosynthetically active radiation (Fig. 5). The resulting cumulative NEE from March 2006 to March 2007 was $45 \pm 20$ and $13 \pm 7 \mathrm{~g} \mathrm{C} \mathrm{m}^{-2}$ for the burned and unburned pastures, respectively, a near-zero or slightly positive source to the atmosphere. Cumulative ecosystem respiration was reduced by roughly 35\% from 2005 to 2006 in both the burned $\left(1250 \pm 120 \mathrm{~g} \mathrm{C} \mathrm{m}^{-2}\right)$ and unburned $\left(1130 \pm 110 \mathrm{~g} \mathrm{C} \mathrm{m}^{-2}\right)$ pastures. This result was similar to that obtained from integrated soil $\mathrm{CO}_{2}$ fluxes from the chamber measurements which were $1210 \pm 30$ and $1080 \pm 30 \mathrm{~g} \mathrm{C} \mathrm{m}^{-2}$ for the burned and unburned pastures, respectively.

\subsection{Inter-annual variations in water and carbon exchanges: effect of drought}

The results of this study suggest that the lack of precipitation was responsible for most of the interannual variation in carbon exchange for these un-irrigated pastures. This is not surprising because precipitation was lower than normal in both 2005 and early 2006, producing drought conditions with lower evapotranspiration and higher sensible heat during the early growth period at the beginning of 2006. These results are broadly consistent with

Table 1

Annual precipitation, peak green biomass, and summed NEE, $R_{\mathrm{eco}}$, and ET.

\begin{tabular}{|c|c|c|c|c|c|c|c|c|c|}
\hline \multirow[t]{2}{*}{ Year } & \multirow[t]{2}{*}{ Precipitation $\left(\mathrm{mm} \mathrm{yr}^{-1}\right)$} & \multicolumn{2}{|c|}{ Annual ET $\left(\mathrm{mm} \mathrm{yr}^{-1}\right)$} & \multicolumn{2}{|c|}{ Maximum green $\mathrm{AGB}\left(\mathrm{g} \mathrm{C}^{-2}\right)$} & \multicolumn{2}{|c|}{ Annual NEE $\left(\mathrm{gC} \mathrm{m}^{-2} \mathrm{yr}^{-1}\right)$} & \multicolumn{2}{|c|}{ Annual $R_{\text {eco }}\left(\mathrm{gC} \mathrm{m}^{-2} \mathrm{yr}^{-1}\right)$} \\
\hline & & Burn & No burn & Burn & No burn & Burn & No burn & Burn & No burn \\
\hline 2005 & 609 & $780(80)$ & $850(90)$ & $450(60)$ & $270(40)$ & $-330(30)$ & $-150(20)$ & $1850(200)$ & $1850(200)$ \\
\hline 2006 & 636 & $680(70)$ & $730(70)$ & $210(30)$ & $140(30)$ & $45(20)$ & $13(7)$ & $1250(120)$ & $1130(110)$ \\
\hline
\end{tabular}



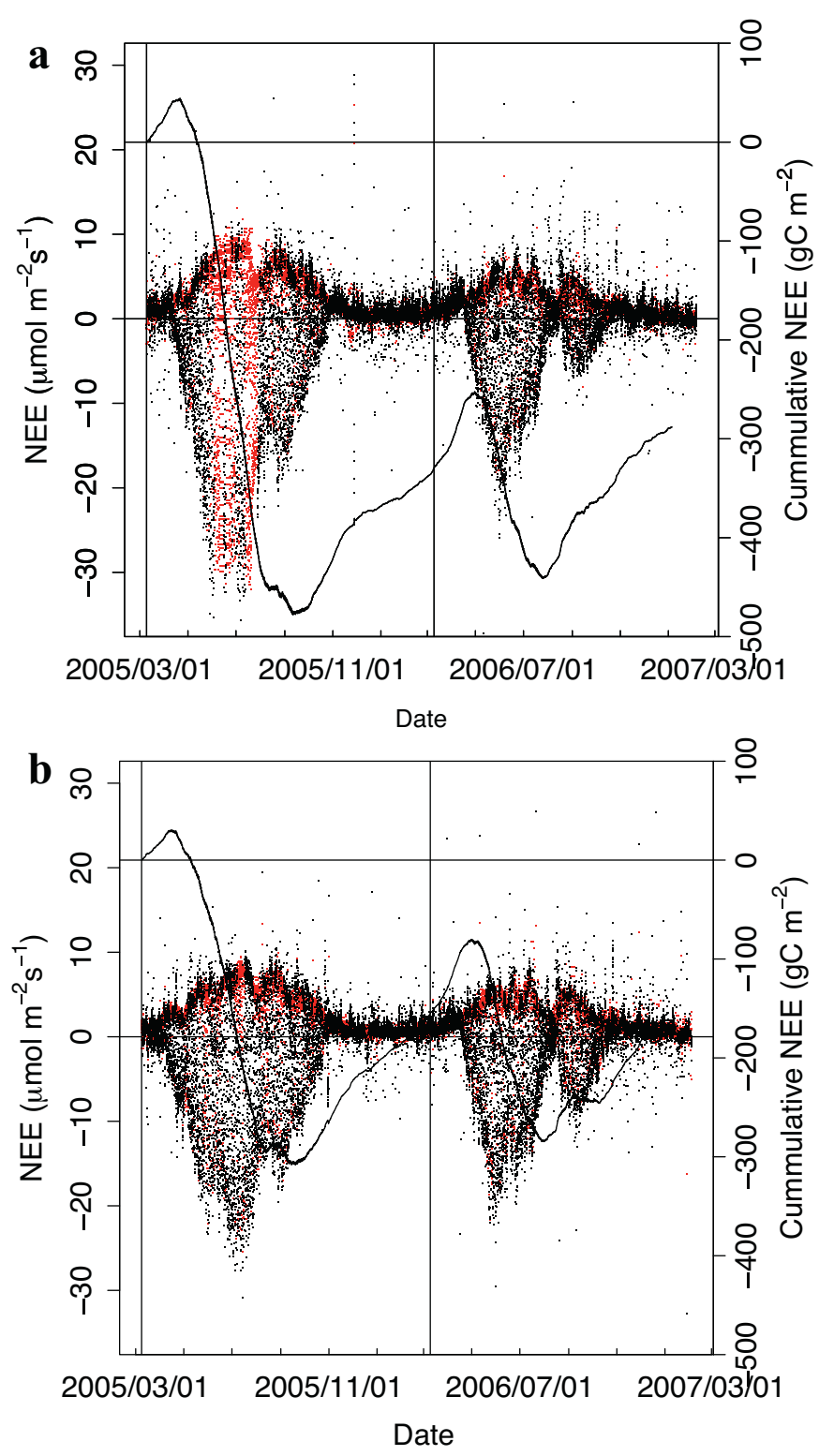

Fig. 4. Time series of NEE in burned (a) and unburned (b) pastures at $1 / 2 \mathrm{hr}$ resolution with gap filled (red) points shown separately. Solid lines show cumulative NEE (on right). (For interpretation of the references to color in this figure legend, the reader is referred to the web version of this article.)

those obtained in a two-year study of burned prairie pastures in Kansas (Bremer and Ham, 2010). In both studies, moisture limitation reduced photosynthetic carbon uptake more than respiration producing a net release of carbon to the atmosphere in some dry years, although the net release observed in the dry year (2006) of our experiment is only marginally significant.

\subsection{Effects of burning on water and carbon exchange}

Because the pastures initially contained different amounts of biomass and may have different productivity, we cannot compare them directly to estimate the effect of the fire. We do note that AGB was approximately the same in March 2006 as before the fire in March 2005 and that the NEE measurements support that the burned pasture accumulated more carbon than that lost in the fire. An interesting result related to water exchange was that both the burned and unburned pastures lost approximately equal amounts

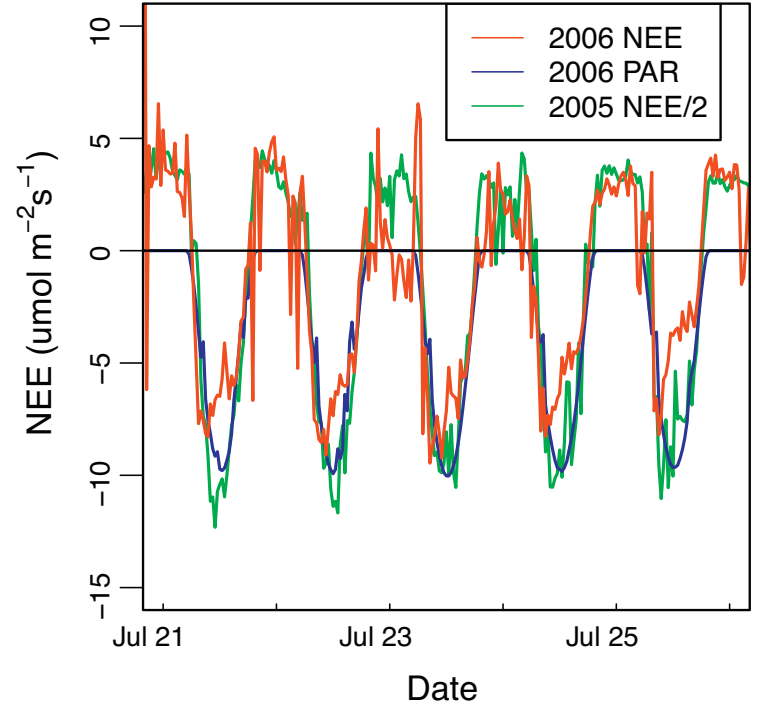

Fig. 5. Diurnal cycles of NEE and PAR (scaled by factor of -0.01) to show reduction in afternoon NEE relative to available light, when available moisture was limiting uptake in July 2006. NEE is also shown for the same week in 2005, when water was not obviously limiting afternoon uptake.

of water, suggesting that either evaporation was suppressed in the burned pasture or water use efficiency was higher.

\section{Conclusions}

The large decreases in biomass production and suppression of carbon dioxide uptake observed between the two years of this study suggest that water availability is a critical factor controlling carbon exchange in these prairie grasslands. Hence, efforts to improve land surface models for grassland ecosystems should focus on capturing the photosynthetic uptake, and decomposition losses to water limitation.

\section{Acknowledgments}

The authors gratefully acknowledge Dr. Herman Mayeaux, former director of the USDA Grazing Lands Research Laboratory, for his vision and assistance in designing and initiating the experiment. We also thank the USDA at El Reno, OK and Patrick Dowell of the USDOE ARM Southern Great Plains ACRF facility for collecting biomass samples and maintaining the instrumentation deployed for this research. This research was supported by the USDA and the Office of Biological and Environmental Research of the U.S. Department of Energy under grant or contract number DE-ACO205CH11231 as part of the Atmospheric Radiation Measurement Program.

\section{References}

Billesbach, D.P., Fischer, M.L., Torn, M.S., Berry, J.A., 2004. A portable eddy covariance system for the measurement of ecosystem-atmosphere exchange of $\mathrm{CO}_{2}$, water vapor, and energy. J. Atmos. Ocean. Tech. 21, 639-650.

Billesbach, D.P., 2011. Estimating uncertainties in individual eddy covariance flux measurements: a comparison of methods and a proposed new method. Agric. Forest Meterol. 151 (3), 394-405.

Bremer, D.J., Ham, J.M., 2010. Net carbon fluxes over burned and unburned native tallgrass prairie. Rangeland Ecol. Manage. 63 (1), 72-81.

Dai, X., Boutton, T.W., Hailemichael, M., Ansley, R.J., Jessup, K.E., 2006. Soil carbon and nitrogen storage in response to fire in a temperate mixed-grass savanna. J. Environ. Qual. 35, 1620-1628.

Falge, E., Baldocchi, D., Olson, R., Anthoni, P., Aubinet, M., Bernhofer, C., Burba, G., Ceulemans, R., Clement, R., Dolman, H., Granier, A., Gross, P., Grünwald, T., Hollinger, D., Jensen, N.-O., Katul, G., Keronen, P., Kowalski, A., Ta Lai, C., Law, B.E., Meyers, T., Moncrieff, J., Moors, E., William Munger, J., Pilegaard, K., 
Rannik, Ü., Rebmann, C., Suyker, A., Tenhunen, J., Tu, K., Verma, S., Vesala, T., Wilson, K., Wofsy, S., 2001. Gap filling strategies for defensible annual sums of net ecosystem exchange. Agric. Forest Meterol. 107 (1), 43-69.

Fischer, M.L., Billesbach, D.P., Riley, W.J., Berry, J.A., Torn, M.S., 2007. Spatiotemporal variations in growing season exchanges of $\mathrm{CO}_{2}, \mathrm{H}_{2} \mathrm{O}$, and sensible heat in agricultural fields of the Southern Great Plains. Earth Interact. 11, 1-21.

Flanagan, L.B., Johnson, B.G., 2005. Interacting effects of temperature, soil moisture and plant biomass production on ecosystem respiration in a northern temperate grassland. Agric. Forest Meterol. 130, 237-253.

Frank, A.B., Dugas, W.A., 2001. Carbon dioxide fluxes over a northern semiarid mixed-grass prairie. Agric. Forest Meterol. 108, 317-326.

Gale, W.J., Kirkham, M.B., Kanemasu, E.T., Owensby, C.E., 1990. Net carbon-dioxide exchange in canopies of burned and unburned tallgrass prairie. Theor. Appl. Climatol. 42 (4), 237-244.

Harper, C.W., Blair, J.M., Fay, P.A., Knapp, A.K., Carlisle, J.D., 2005. Increased rainfall variability and reduced rainfall amount decreases soil $\mathrm{CO}_{2}$ flux in a grassland ecosystem. Global Change Biol. 11 (2), 322-334.

Heisler, J.L., Briggs, J.M., Knapp, A.K., 2003. Long-term patterns of shrub expansion in a $C_{4}$-dominated grassland: fire frequency and the dynamics of shrub cover and abundance. Am. J. Bot. 90, 423-428.

King, A.W., Dilling, L., Zimmerman, G.P., Fairman, D.M., Houghton, R.A., Marland, G.H., Rose, A.Z., Wilbanks, T.J., 2007. The first state of the carbon cycle report (SOCCR): the North American carbon budget and implications for the global carbon cycle. http://cdiac.ornl.gov/SOCCR/documents.html.

Knapp, A.K., Conrad, S.L., Blair, J.M., 1988. Determinants of soil $\mathrm{CO}_{2}$ flux from a subhumid grassland, effect of fire and fire history. Ecol. Appl. 8, 760-770.

Moore, C.J., 1984. Frequency Response Corrections for Eddy Correlation Systems. Bound.-Lay. Meteorol. 37, 17-35.

Meyers, T.P., 2001. A comparison of summertime water and $\mathrm{CO}_{2}$ fluxes over rangeland for well watered and drought conditions. Agric. Forest Meterol. 106, 205-214.

Mielnick, P.C., Dugas, W.A., 2000. Soil $\mathrm{CO}_{2}$ flux in a tallgrass prairie. Soil Biol. Biochem. $32,221-228$.

Norman, J.M., Garcia, R., Verma, S.B., 1992. Soil surface $\mathrm{CO}_{2}$ fluxes and the carbon budget of a grassland. J. Geophys. Res. 97, 18845-18853.
Owensby, C.E., Ham, J.M., Auen, L.M., 2006. Fluxes of $\mathrm{CO}_{2}$ from grazed and ungrazed tallgrass prairie. Rangeland Ecol. Manage. 59, 111-127.

Polley, W.H., Frank, A.B., Sanabria, J., Phillips, R.L., 2008. Inter-annual variability in carbon dioxide fluxes and flux-climate relationships on grazed and ungrazed northern mixed-grass prairie. Global Change Biol. 14, 1620-1632.

Randerson, J., Chapin, F., Harden, J., Neff, J., Harmon, M., 2002. Net ecosystem production: a comprehensive measure of net carbon accumulation by ecosystems. Ecol. Appl. 12, 937-947.

Schimel, D.S., 1995. Terrestrial ecosystems and the carbon cycle. Global Change Biol. $1,77-91$.

Schlesinger, W.H., 1997. Biogeochemistry: An Analysis of Global Change. Academic Press/Elsevier, San Diego, CA.

Svejcar, T.R., Angell, R., Bradford,J.A., Dugas, W., Emmerich, W., Frank, A.B., Gilmanov, T., Haferkamp, M., Johnson, D.A., Mayeux, H., Mielnick, P., Morgan, J., Saliendra, N.Z., Schuman, G.E., Sims, P.L., Snyder, K., 2008. Carbon fluxes on North American rangelands. Rangeland Ecol. Manage. 61, 465-474.

Sims, P.L., Bradford, J.A., 2001. Carbon dioxide fluxes in a southern plains prairie. Agric. Forest Meterol. 109, 117-134.

Suyker, A.E., Verma, S.B., Burba, G.G., 2003. Inter-annual variability in net $\mathrm{CO}_{2}$ exchange of a native tallgrass prairie. Global Change Biol. 9 255-265.

USDA-NRCS, 1999. Soil survey of Canadian county, Oklahoma. Supplement manuscript. USDA-NRCS and Oklahoma Agricultural Experiment Station, Stillwater, OK.

Webb, E.K., Pearman, G.I., Leuning, R., 1980. Correction of Flux Measurements for Density Effects due to Heat and Water Vapour Transfer. Quart. J. Roy. Meteorol. Soc. $106,85-100$

Zhang, L., Wylie, B.K., Ji, L., Gilmanov, T.G., Tieszen, L.L., Howard, D.M., 2011. Upscaling carbon fluxes over the Great Plains grasslands: sinks and sources. J. Geophys. Res. 116, G00J03, http://dx.doi.org/10.1029/2010JG001504.

Zhou, X., Sherry, B., An, Y., Wallace, L.L., Luo, Y., 2006. Main and interactive effects of warming, clipping, and doubled precipitation on soil $\mathrm{CO}_{2}$ efflux in a grassland ecosystem. Global Biogeochem. Cycles 20, GB1003, http://dx.doi.org/10.1029/2005GB002526. 